DOI: 10.17707/AgricultForest.62.1.12

\author{
Sergey V. GONCHAROV ${ }^{I}$
}

\title{
CEREALS BREEDING \& SEED BUSINESS IN RUSSIA: CURRENT DEVELOPMENT AND PROSPECTS
}

\begin{abstract}
SUMMARY
Winter wheat is cultivated at 13.1 ha in Russia. Volume of the domestic seed market is estimated at $\$ 2$ bln, while the share of commercial seeds is $\$ 1$ bln. The highest yields (about 5 tons per ha) are harvested by farmers of Southern region. Production risks are much higher in Central part, and Middle Volga. There are 292 winter wheat varieties listed in the National Register in 2015; 98\% of them are local ones. Krasnodar Institute is on the top of winter wheat breeder's rating list, out of about 50 domestic breeders. SWOT analysis of national breeding programs showed, their strengths are reach gene pool, and traditional selection methods. Institution network in range of zones, varieties adaptation especially in low-, and average income segments;, intellectual property IP rights similarity to European ones, and others are also strengths. Weaknesses are old infrastructure and equipment's; limited access to modern technologies; autocratic management; poor breeders motivation etc. Opportunities are possible collaboration development; trailing in different climate zones; seed market potential growth, etc. Realty as subject of raiders attacks; agricultural policy unpredictability; "dyeing" some breeding programs due to cost; erosion of genetic resources; mutual sanctions; availability of know-how and hi-tech in breeding are threats. Full life cycle of variety lasts from 26 to 30 years. Royalty market of winter wheat certified seeds are assessed as $\$ 3.4 \mathrm{~m}$
\end{abstract}

Keywords: breeding programs, winter wheat, seed market, variety life circle, royalty rate.

\section{INTRODUCTION}

Russia has got $9 \%$ of the world's arable land with $26 \%$ of the most fertile soils globally [Alabushev A. 2010; Medvedev A.2009; Shamaev V. 2014 ].Agricultural sector accounts for $4.1 \%$ of the country's GDP as of 2013, which declined from 5,6\% in 2010. Grain production is a key sector of agriculture with gross wheat yields $58 \mathrm{~m}$ tons in 2014, and as a result, Russia is of the important grain exporter. However, country should play a greater role on the world markets of food and feed supply in near future because of available agro-climatic resources.

\footnotetext{
${ }^{1}$ Sergey V. Goncharov, (corresponding author: slogan1960@mail.ru), Voronezh State Agricultural University, RUSSIA

Paper presented at the $6^{\text {th }}$ International Scientific Agricultural Symposium "AGROSYM 2015".

Notes: The authors declare that they have no conflicts of interest. Authorship Form signed online.
} 
Main constrains in the development of agriculture is low market financing of arable land [Shamaev V. 2014]. State regulation of the grain market is controversial; the allocation of resources between agriculture, processing, trade, banks is not optimal, and at the expense of agricultural production. Limitation of commodity wheat exports by imposing export duties in 2015 , and devaluation of local currency reduce market funding farmers, exacerbated by the increased interest rates. The domestic market is not able to compensate the farmers loses from the restriction of export facilities, which reduce intensification (and cost of seeds).

The objective of the article is to assess competiveness of Russian crop breeding and seed production complex on the example of winter wheat (Triticum aestivum $\mathrm{L}$.)

\section{MATERIAL AND METHODS}

National Registers of Belorussia, Germany, Kazakhstan, Russia, and Ukraine, official statistics of Russia and USDA, results of author's market researches, and market assumptions were used as sources of information. Domestic breeding programs are assessed with SWOT analysis. Commercial variety life circle calculation is based on author's methodology [Goncharov S. 2013].

\section{RESULTS AND DISCUSSION}

Average yields of winter wheat grew up about $5 \mathrm{Dt}$ per ha in Russia for last 30 years, what is significantly less, then in USA (+7 Dt/ha), and in China (+20 Dt/ha) mainly due to laggard in breeding (fig.1).

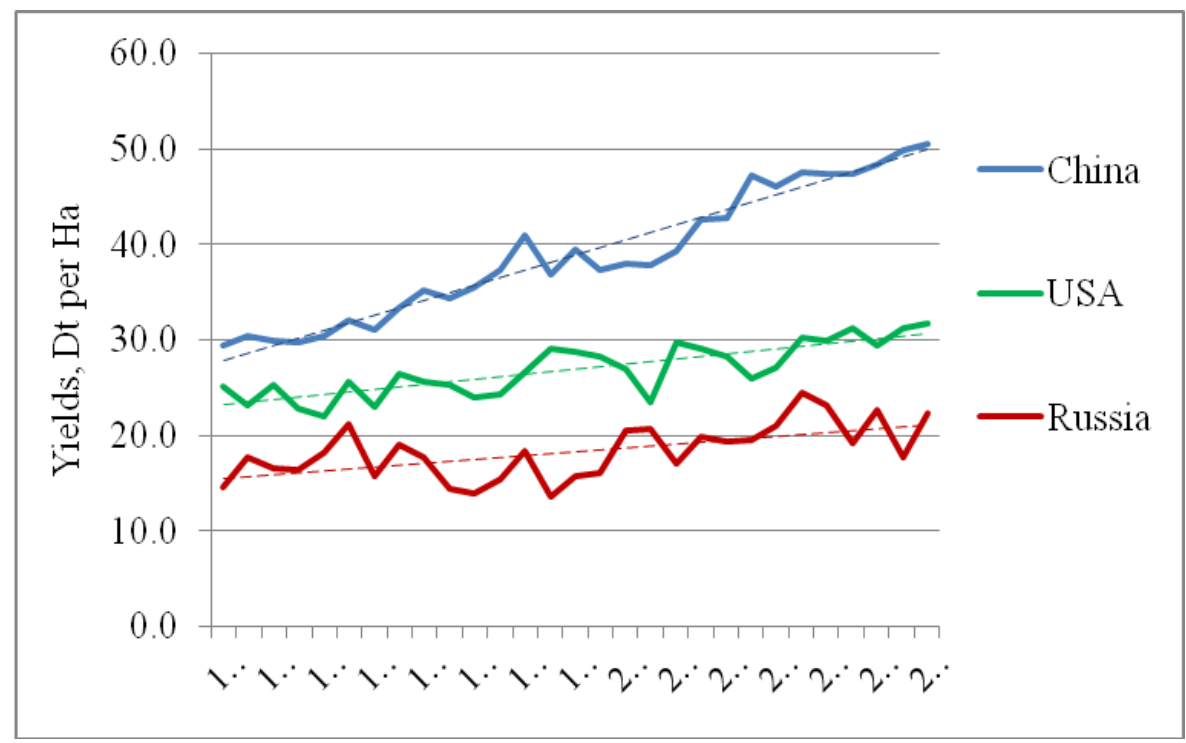

Fig.1 - Wheat yields in China, USA, and Russia, Dt per Ha (source http://faostat3.fao.org/download/Q/QC/E) 
Seed is a key factor of agricultural prospects, as other agricultural inputs efficacy depends on them in a big scale. Appropriate seeds qualityis required to meet the demand of diverse climate conditions and cropping systems. Sustainable agricultural production depends on adapted varieties flow, crops production and efficient channels of quality seeds supply to the farmers [Medvedev A.2009; Alabushev A. 2010; Goncharov S. 2013]. Volume of the domestic seed market is estimated at $\$ 2 \mathrm{bln}$, while the share of commercial (marketed) seeds does not exceed $\$ 1$ bbln.

The seed sector of ex-Soviet Union was well organized and was controlled by State planned economy. Despite current attempts to reform it, the overall situation remains practically unchanged. Seed industry faces a major challenge in terms of deteriorating material and technological base for the breeding and lack of infrastructure required to supply quality seeds for the farmers. Developing import substitution policy, the State declares breeding \& seeds business support as much as 41,4 bln rubles [RUR] in 2015-2020.

The share of sowing seeds having local origin is high only for cereals and legumes which accounted for $96 \%$ of the total market. Wheat production provides turnover as $\mathbf{5 7 0} \$ /$ ha in South of the country (June 2015), but only 300 $\$ /$ ha in Siberia due to difference in yields, and commodity prices. Wheat yields in Krasnodar region are highest in the country compare to Stavropol and Rostov ones (located in South as well), but even more compare to yields in Voronezh and Belgorod ones (Central Region). Average yields in Krasnodar region improved +20 Dt per ha within period since 1996 to 2014, compare to these in Voronezh region (+8 Dt per ha) (fig.2).

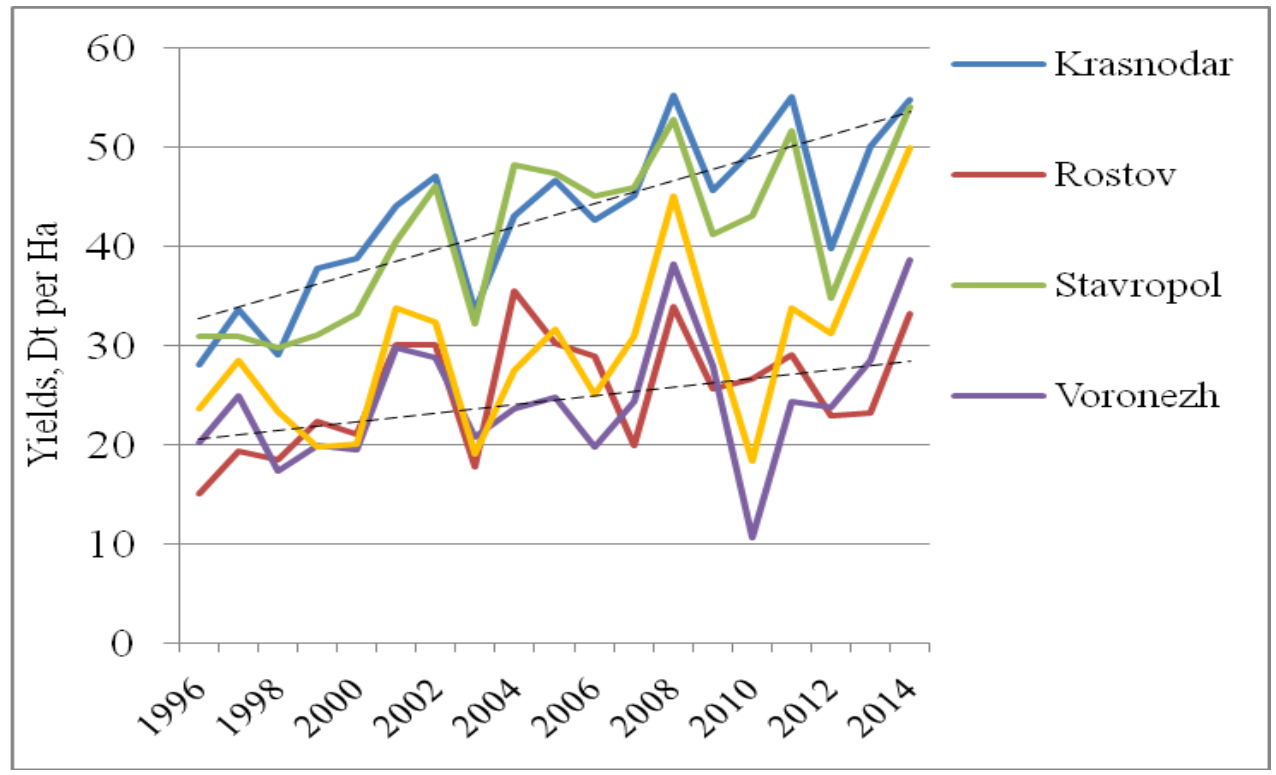

Fig. 2 - Winter wheat yields in regions of Russia, Dt per ha (source http://www.gks.ru/bgd//regl/b08 11) 
South of Russia is the "grain basket" of the country by cultivation areas, number of listed winter wheat varieties, and substantialyields as well. There are 292 winter wheat varieties from about more than 50 applicants in the National Register; 98\% are local ones. Out of them 10 top-leaders are grown at $40 \%$ territory of the crop acreage. Central Russia and Middle Volga are also zones of winter wheat production, but with higher risks.

Varieties of market leader Krasnodar Institute by Luk'yanenko name (KNIISH) are cultivated at $98 \%$ winter wheat area $(1.2 \mathrm{~m} \mathrm{ha})$ of Krasnodar region, at $50 \%$ area of Stavropol region $(1.7 \mathrm{~m} \mathrm{ha})$, about $20 \%$ of Rostov region ( $2 \mathrm{~m} \mathrm{ha}$ ).KNIISH is only breeder of 44 listed wheat varieties, and is additionally co-author of about 30 joint bred ones. Bred $25 \%$ of the varieties listed in National Register (Grom, Irishka, Juka etc.) KNIISH puts in registration up to 10 applications annually: 4-5 of them will be listed then. KNIISH is also commercializes their varieties in Ukraine, Armenia, Azerbaijan, and Turkey. Its varieties are cultivated about at $24 \%$ areas of winter wheat in this country (fig.3). Academic L.A. Bespalovaleads leads wheat breeding program there [3].

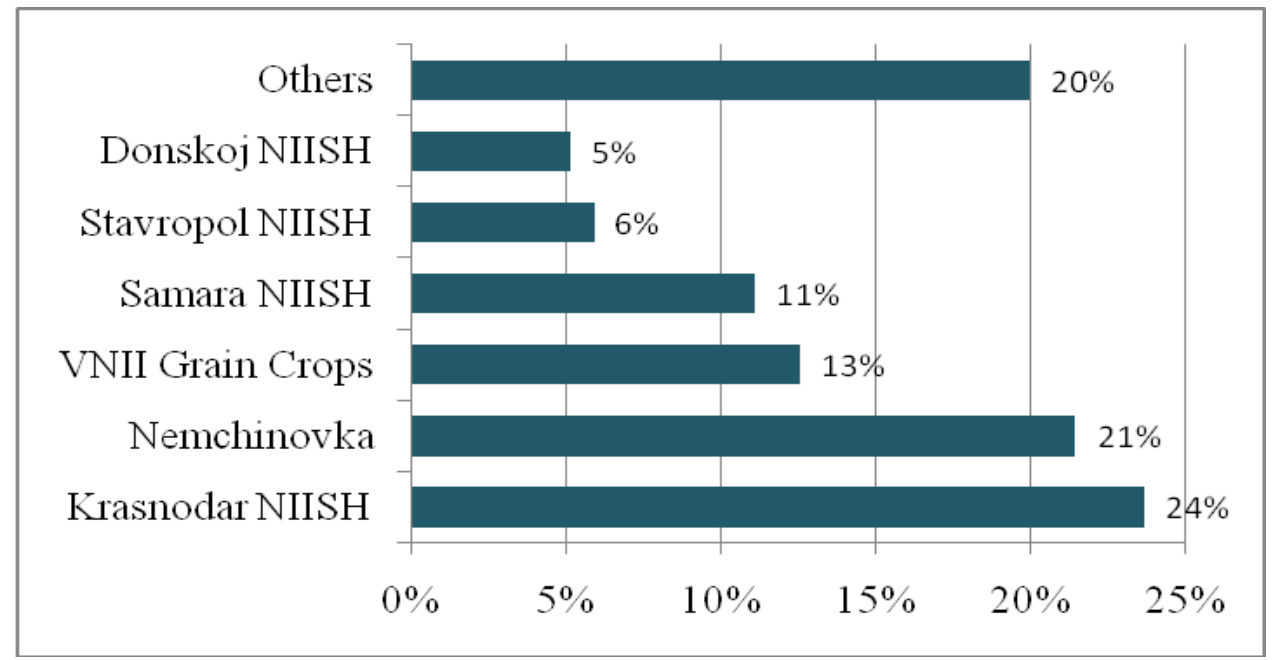

Fig. 3 - shares of winter wheat top breeders in russia, $\%$ of cultivated areas

All 12 listed varieties of the Moscow Research Institute of Agriculture "Nemchinovka" domain in the non-Chernozem zone, in the northern and central part of the Central Chernozem region. They are cultivated at 95\% areas in Oryol region (out of $0.3 \mathrm{~m} \mathrm{ha}$ ), at $40 \%$ in Lipetsk region $(0.35 \mathrm{~m}$ ha), almost at $60 \%$ in Tambov region $(0.32 \mathrm{~m} \mathrm{ha})$, and $12 \%$ in Voronezh region $(0.6 \mathrm{~m}$.ha). Such varieties as Moskovskaya 39, Moskovskaya 56, Galina are still market leaders there. Academic B.I. Sanhukhadze is the senior breeder.

33 listed varieties bred byNational Research Institute of Grain Crops by Kalinenko name (VNII Grain Crops) domain in Rostov region, occupy 14\% of winter wheat areas in Stavropol region, and about 25\% in Voronezh one $(0.6 \mathrm{~m}$ 
ha). Its market share is declining due to resign of Dr. V.I. Kovtun, the ex-head of breeding department, who is employed by Stavropol NIISH now. Such varieties, as Severodonskaya jubilejnaya, Don 95, Donskoj sjurpriz, Donskaya bezostaya bred by VNII Grain Crops, used to be market-leaders in different years.

The Donskoj Zone Institute distributes seeds of its 16 listed varieties (Gubernator Dona, Donako, Donskaya Lira etc.) in centraland eastern parts of European Russia.Samara Research Institute (Samara NIISH) and Stavropol Research Institute (StNIISH) are in top-6 list of national winter wheat breeders, and their products are well presented in Mid-Volga and Southern regions correspondingly.

The success of local breeding programs took place in $\mathrm{xx}$ century due to genetics development and the implementation of crossing and selection methods. However, backlog, accumulated the last 30 years as only a few local breeding programs relay on innovative technologies. Using the methods of dna sequencing, genetic distance study, marker selection and di-haploids production in the connections with conventional breeding provide their owner thecompetitive advantages.higher adding value of "innovated" varieties provides their better competiveness in commercial use.

They are sulpho-, and imidozalinon-tolerant hybrids and conventional varieties, "stay green" effect of corn, "nully-lox" malting barley varieties etc. Further yield potential growth due to hetherosis effect is expected by cereals hybrids commercialization. As a breeding is low business in this country, private breeding programs due to high interest rate (15-20\%), and inflation (8\%).

Traditional sources of local breeding programs funding are 1) the state budget, which recoups staff salaries expenses; 2) off-budget funds are spent on breeding program running (equipment and facilities, fuel, fertilizers, plant protection, etc.) Off-budget funds are also including royalties. Share of the offbudget is not sufficient.

Strengths of domestic breeders are: diverse genetic resources; the network of research stations and universities in different soil-climatic zones and, as a consequence, adaptation of varieties to local conditions, stress-, and diseases tolerance. The approved IP rights system is similar to the European one. The traditions and continuity of scientific schools, which were developed in the USSR, are also there.

Weaknesses are outdated equipment and facilities, an excessive bureaucracy. Breeders are poor motivated, and aged scientific staff is common. Commercial funding is not satisfactory; institutes share profits from the use of breeding varieties (not breeders), so investments in research and development $(\mathrm{r} \& \mathrm{~d})$ are insufficient. There is a lack of modern methods of increasing the efficiency of traditional selection. Official trialing don't provide objective results due to low-, and average input there. There is a lack of the necessary 
infrastructure to ensure farmers get quality seeds, varietal weakness policy and legislative framework. Breeders are poorly informed about the processors and grain trader needs in value chains.

Table 1. SWOT analysis of domestic breeding programs

\begin{tabular}{|l|l|}
\hline Strength & Weakness \\
-Gene pool & -Old infrastructure and equipment's \\
-Traditional selection & -Limited access to modern \\
-Institution network in range of & technologies \\
zones & -Burocratic management \\
-Varieties adaptation & -Poor motivation of breeders \\
-Low-, and average income & -Shortage of market funding \\
segments & -Registration (timing, transparency, \\
-UPOV membership & low input) \\
-IP similar to European ones & -Seed business constrains \\
-Scholarship \& traditions & -Pain point \& needs of processors \\
-State support & uncetainty by breeders \\
\hline Opportunities & Threats \\
-Collaboration development & -Realty as subject of raiders attacks \\
-Trialing in different climate zones & -Agricultural policy unpredictable \\
-Seed market potential (growth & -Some breeding programs to stop \\
commercial seed share) & due to low effecacy \\
-Private investments in breeding & -Erosion of genetic resources \\
programs & -Mutual sanctions: availability of \\
-CIS market demand growth & know-how and hi-tech in breeding \\
-Privatization of local institutes & -Breeding programs to stop \\
-Import substitution program & \\
\hline
\end{tabular}

Opportunities of the local breeding programs are in development of cooperation, particularly in the trialing in different zones. Collaboration with western seeds companies facilitates market approach. Growing capacity of the grain market increases demand of new varieties and high quality seeds by farmers. Share of commercial seeds is going to grow up since $8 \%$ nowadays to $12-15 \%$ in 10 years. Private seed companies make attempts to invest in crop breeding. New domestic varieties have good chances to be distributed in other republics of the cis cue to similarity of geographical, cultural and economic conditions. About $1 / 4$ varieties in the state register have 2 or more of originator (institutes), what proves needs of trialing network in different climate conditions and regions; that's another prospect of possible cooperation development. Further r\&d institutes privatization will give an impetus to their development. Current state policy of import substitution is additional support of local breeding varieties. There are a range of threats in this country. Breeders are not 
independent; they are part of institutes or stations. Most of local $r \& d$ centers possess properties (land, realty etc. From ex-ussr times).raider schemes for disposing of valuable properties are the greatest threat for the local $r \& d$, and for breeding programs as well, as many institutes are located in the territory of big cities. So, price of realty is high. Lobbying of domestic varieties and hybrids leads to possible breeding postponing due to shortage of competitiveness. Other threats are uncertainty of agricultural policy in general and the unpredictable effects "manual control" of the economy, and thus legal uncertainty. Government doesn't allow bio-tech, gm-researches to be developed properly. Substantial number of breeding programs may be ceased due to insufficient return of investment.

Commercialization of awheat variety begins together with seeds sale, which coincides with its registration in the state register, and overs with its exception, termination of seed production and seeds sale. Currently the average period of commercial use, or winter wheat life circles in this country is 13 years. It is shorter, then 17 years for spring barley, and 20 ones spring wheat [goncharov s. 2013]. Generally, life circle of winter wheat variety in russia has the sameduration, as in germany, but longer compare to belorussia, and ukraine (fig. 4)

Taking in consideration duration of selection of the winter wheat variety is 10-12 years, the registration lasts for 3-4 years, and commercial use doesfor 13 years, a

full cycle of a variety is from 26 to 30 years on average. Breeder should for esee needs of consumers and processors as well at least 15-25 years forward.

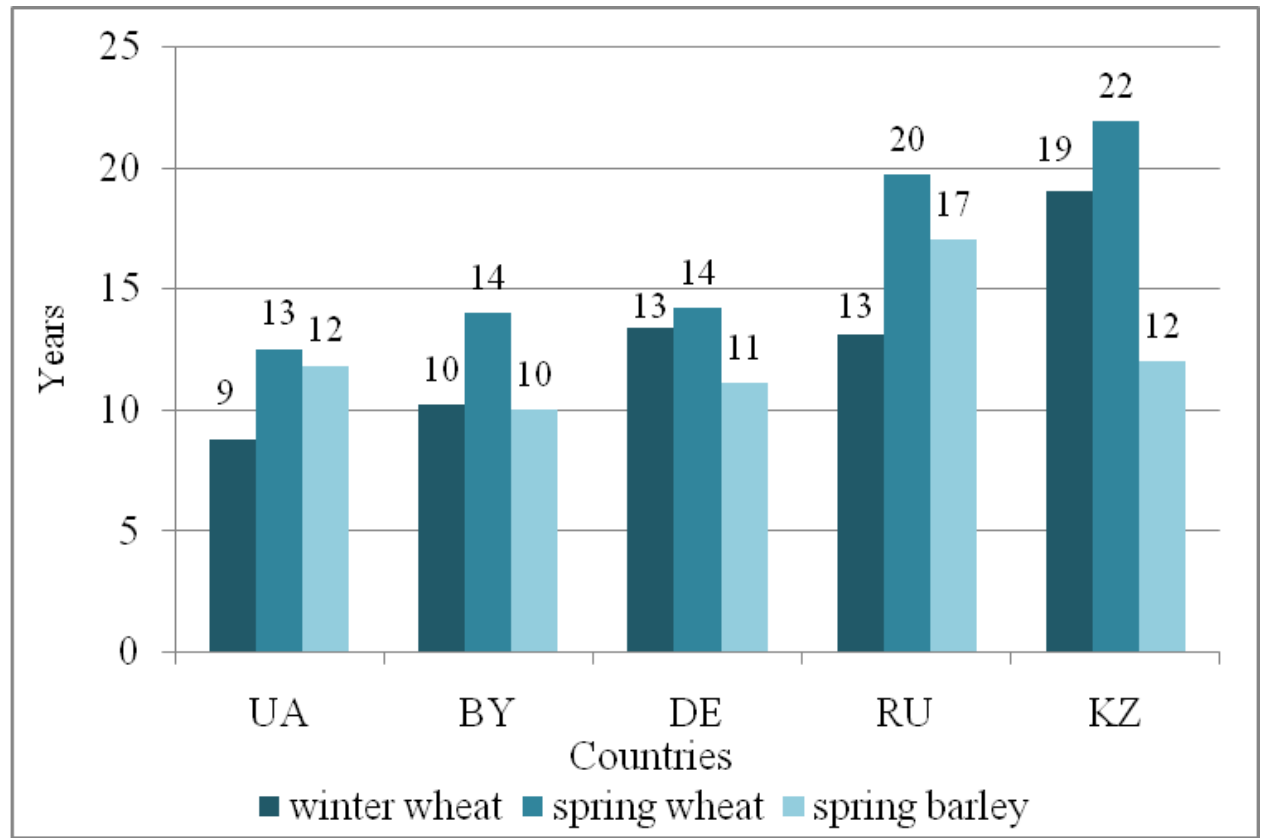

Fig. 4.-Commercial life circle length of cereals varieties in different countries, years [4]. 
Winter wheat acrage reaches $13.1 \mathrm{~m}$ ha in russia, and with seeding rate as $0.23 \mathrm{t} / \mathrm{ha}$, the seeds demand is $2.97 \mathrm{~m}$ tons. However, with $8 \%$ share of the commercial seed, actual demand is $0.24 \mathrm{~m}$ tons. Considering average price of selling seeds as 15 th.rur./t, and average royalty rate as $5 \%$ of 1 ton of seed price, the potential of royalty market is $180 \mathrm{~m} \operatorname{rur}(\$ 3.4 \mathrm{~m})$. Royalties for farm saved seeds are not common in this country.for comparison, winter wheat area of germany as $3.2 \mathrm{~m}$ ha with seeding rate as $0.14 \mathrm{t} / \mathrm{ha}$ needs $0.45 \mathrm{~m}$ tons of seeds (goncharov, 2013). Considering 45\% share of the commercial seeds, their volume amounted as $0.20 \mathrm{~m}$ tons. Multiplying the amount of commercial seed at the average royalty rate $(73 \$ / \mathrm{t})$ get market volume royalties as $\$ 14.6 \mathrm{~m}$ (without farm saved seeds -fss royalties).

There are more than 50 local winter wheat breeding institutes and stations in russia compare to 13 ones in germany. Thus, royalty income of german breeder exceed those in russia, what allows to select more varieties with higher added value through the use of modern methods and hi-tech approaches. Up to $10-15 \%$ of the turnover of german seed companies invested in $\mathrm{r} \& \mathrm{~d}$.

Low market financing of arable land (per hectare revenues in the production of wheat) in russia has direct impact on sustainable development of breeding programs. Seed market development may be imposed via:

-commercial seeds share rising from $8 \%$ nowadays till $12-15 \%$ in 10 years;

-privatization of breeding institutes, and stations;

-state investment in r\&d, and in high-tech especially;

-concentration and industrialization of seed business; about 20 cereals processing plants with capacity 250 th.tons were built for last 15 years.

-legal adjustment (fss royalty collection);

Competitive advantages of cereals seeds may be shorter variety life circle, higher adding value of varieties, switch to cereals hybrids due to quick return of investment in breeding, and adequate business-models. But portfolio management is implemented usually by institute's authority, which don't have sufficient marketing knowledge.

Domestic $r \& d$ needs substantial investment to fill information gaps, to conduct researches and to ensure the implementation of environmental technologies in agriculture. Climatic changes increase the level of investment needs required to reach food securitymainly via crop breeding. This requires additional state investments, as private capital prefers to invest in short-term projects with quick return. The government should improve the data collection mechanisms and to ensure farmers know-how and seeds for their adaptation to new challenges.

\section{CONCLUSIONS}

1) Status of breeding and seed production complex of the country depends on the efficiency of agriculture in general and from market funding of arable land in particular. 
2) National cereals breeding programs don't meet new challenges in a full scale due to poor State and market financing (high FSS, limited royalty market etc.)

3) Commercial life circle of wheat variety lasts 13 years on average.

4) Winter wheat royalty market value is $\$ 3.4 \mathrm{~m}$.

5) Institute privatization, and State investments in high-tech as shares of R\&D reforming should be implemented to improve competiveness of crop breeding.

\section{REFERENCES}

Alabushev A. 2010. Gureeva A., Raeva S., Current situation and prospects of development cereals seeds in Russia. Grain husbandry of Russia.№ 6(12).P.13-16.

GoncharovS. 2013.Competiveness of national breeding programs. Herald of VSAU.V 2(37).P. 176-183.

Goncharov S. 2013. Wheat seed market of Europe. Herald of VSAU.V. 2(37).P.169-175.

Goncharov S. 2013. Actual duration of cereals variety life circle. Crop production: scientific results and prospects. Voronezh. VSAU.P. 63-69.

Medvedev A.2009. Improvement of seed multiplication of crops.Seed legal base adjustment. Kursk. P. 52-57.

Shamaev V. 2014. Mathematics of Russian arable land and geometry of market stock. www.agrospeaker.ru/var/fck/file/AGROSPEAKER_book.rar 